\title{
The cashew (Anacardium occidentale) industry in Côte d'Ivoire: analysis and prospects for development
}

\author{
Doudjo SORO ${ }^{1,2 *}$, Manuel DORNIER ${ }^{1}$, Fernando ABREU ${ }^{3}$, Emmanuel ASSIDJO ${ }^{2}$, Benjamin YAO $^{2}$, Max REYNES ${ }^{1}$
}

\author{
1 UMR 95 Qualisud, CIRAD, \\ Montpellier-SupAgro, \\ TA B-95 / 16, \\ 73, rue J.F. Breton, \\ 34398 Montpellier Cedex 5, \\ France \\ dousoro@yahoo.fr \\ 2 Lab. Procédés Ind. Synth. \\ Environ. (LAPISEN), Inst. NtI. \\ Polytech. Félix Houphouët- \\ Boigny (INP-HB), BP 1313, \\ Yamoussoukro, Côte d'Ivoire \\ ${ }^{3}$ Empresa Bras. Pesqui. \\ Agropecu. (EMBRAPA), \\ Agroind. Trop., rua Dra Sara \\ Mesquita, 2270 Planalto do \\ Pici, Caixa Post. 376, CEP \\ 60511-110, Fortaleza CE, \\ Brésil
}

* Correspondence and reprints

Received 13 May 2010 Accepted 7 October 2010

Fruits, 2011, vol. 66, p. 237-245 (C) 2011 Cirad/EDP Sciences All rights reserved DOI: $10.1051 /$ fruits/2011031 www.fruits-journal.org

RESUMEN ESPAÑOL, p. 245

\section{The cashew (Anacardium occidentale) industry in Côte d'lvoire: analysis and} prospects for development.

Abstract - Introduction and history of cashew cultivation. The location of Côte d'Ivoire promotes the cultivation of cashew (Anacardium occidentale) in the northern half of the country. Indeed, introduced in 1960 to fight against erosion and halt the advancing desert, this crop has become a perennial source of income for more than 150,000 farmers gathered in twenty cooperatives and allows more than $1.5 \mathrm{M}$ people to earn a living. The Ivorian cashew production increased from 6,000 t.year ${ }^{-1}$ in 1990 to $330,000 \mathrm{t}^{\prime}$ year ${ }^{-1}$ in 2008, with a forecast of $350,000 \mathrm{t}^{-y_{e a r}-1}$ in 2009 . Organization of the cashew sector. However, the sector is facing enormous problems including the disorganization of operators and the non-processing of cashews. The disorganization of the sector's operators does not promote collaborative resolution of issues of common interest. This results in all sorts of speculation by intermediaries. The existing structures do not work synergistically, so that the price of cashew per kg paid to producers varies in the same country, from one region to the other, and even according to the buyers. Strategic and institutional environment. The problems of processing cashew nuts are due on the one hand to the investment code that does not favor the installation of medium-sized processing units $\left(2,500 \mathrm{t}^{\prime} \mathrm{year}^{-1}\right)$ and, on the other hand, to private banks which require too many guarantees to fund investors. Conclusion. The cashew industry has a future in Côte d'Ivoire provided that the operators are organized, and that the Ivorian state establishes a regulatory and institutional framework to facilitate the installation of investors.

Côte d'Ivoire/ Anacardium occidentale / cashews / industry / marketing channels / cooperative processing / market intelligence / price formation

L'industrie de la noix de cajou (Anacardium occidentale) en Côte d'Ivoire : élément d'analyse et perspectives pour son développement.

Résumé - Introduction et histoire de la culture de l'anacarde. La situation géographique de la Côte d'ivoire favorise la culture de l'anacarde (Anacardium occidentale) dans la moitié nord du pays. En effet, introduite dans les année 1960 pour lutter contre l'érosion et freiner l'avancée du désert, cette filière est devenue une culture pérenne génératrice de revenus pour plus de 150000 producteurs regroupés dans une vingtaine de coopératives et faisant vivre plus de $1,5 \mathrm{M}$ de personnes. La production ivoirienne est donc passée de $6000 \mathrm{t} \cdot \mathrm{an}^{-1}$ en 1990 à $350000 \mathrm{t}^{-\mathrm{an}^{-1}}$ en 2008 avec une prévision de $350000 \mathrm{t} \cdot \mathrm{an}^{-1}$ en 2009 . Organisation du secteur de l'anacarde. Cependant cette filière est confrontée à d'énormes problèmes dont l'inorganisation des opérateurs et la non transformation des noix de cajou. L'inorganisation des opérateurs de cette filière ne favorise pas la résolution concertée des problèmes d'intérêts communs. Cela se traduit par toutes sortes de spéculation par les intermédiaires. Les structures existantes ne travaillent pas en synergie, si bien que le prix du kg d'anacardes payé aux producteurs varie au cours de la même campagne, d'une région à une autre et même en fonction des acheteurs. Stratégie et environnement institutionnel. Les problèmes de transformation des noix de cajou sont dus, quant à eux, d'une part au code d'investissement qui ne favorise pas l'installation d'unités de transformation moyennes (2 $500 \mathrm{t} \cdot \mathrm{an}^{-1}$ ) et, d'autre part, aux banques privées qui exigent trop de garanties pour financer les investisseurs. Conclusion. La filière de la noix de cajou a de l'avenir en Côte d'Ivoire pourvu que les opérateurs s'organisent et que l'Etat ivoirien mette en place un cadre réglementaire et institutionnel pour favoriser l'installation des investisseurs.

Côte d'Ivoire / Anacardium occidentale / noix de cajou / industrie / circuit de commercialisation / coopérative de transformation / information sur le marché / formation des prix 


\section{Introduction}

The location of Côte d'Ivoire promotes the cultivation of fruit trees as well as seasonal and perennial crops. The cultivation of cocoa, coffee and rubber takes place in the dense forest and forest planted with trees while, in the savannah and grassland, it is the cultivation of cashew and cotton that predominates.

The cultivation of cashew (Anacardium occidentale) was introduced in Côte d'Ivoire in the 1960s to halt the advancing desert and fight against erosion. This culture has been successful since 1997 because of the high price of cashew nuts on the international market. Thus, from 1990 to 2008, the Ivorian production increased from $6,000 \mathrm{t}$ to $330,000 \mathrm{t}$, making the country the 2 nd world producer of cashew after India [1, 2].

Despite this significant increase, the Ivorian cashew industry is facing difficulties. During our analysis on this sector, we review the history of this crop. Then, we discuss the organization of the sector and its strategic and institutional environment. Finally, an analysis of the potential processing of cashew and its co-products allowed us to understand how this crop can contribute to the socio-economic development of Côte d'Ivoire.

\section{History of the cultivation and the processing of cashew in Côte d'Ivoire}

The cultivation of $A$. occidentale was introduced in Côte d'Ivoire in the 1960s by the Ivorian state through the reforestation plan for the savannah zone and the fight against erosion [1-3]. Thus, from 1959 to 1967 , SODEFOR (Forest Development Company) established 1,400 ha of cashew plantations in the region of Korhogo (Savannah region), while, between 1965 and 1969, SATMACI (Company for Technical Assistance for the Modernization of Agriculture in Côte d'Ivoire) planted 820 ha. As this crop was not a source of financial income, it was neglected until 1972. From that date, as part of a program to boost the cultivation and marketing of cashew nuts, the Ivorian government created the state company SOVANORD (Company for the Development of Northern Cashew). As for the SATMACI plantations, they were assigned to the SODEFEL (Company for the Development of Fruits and Vegetables) to create fruit plantations and not forest ones [4, 5]. As the plantations which had densities of about 2,500 trees $\cdot \mathrm{ha}^{-1}$ were lightened to increase the production yield in cashew, these plantations were handed over to village communities [1, 2, 4].

In 1976, SOVANORD created a shelling unit in Korhogo; it was called AICI (Côte d'Ivoire Cashew Industry). This unit dealt with $1,500 \mathrm{t}^{\text {nuts year }}{ }^{-1}$ using Oltremare technology, which is also called Italian or modern technology compared with the Indian technology. In 1980, the plant failed and the marketing of raw nuts fell into the hands of private companies specialized in trading [1]. In 1993, as part of the privatization of state companies, Ivorian executives bought the unit and renamed it AISA (Cashew Industry, Ltd.). But, because of mismanagement, the new company shut down production after 3 years of operation. In 1998, AFRECO (African Trade), specialized in the trading of raw cashew nuts, left AISA and renamed it CAJOUCI (Côte d'Ivoire Cashew) The plant operated from 1998 to 2002 with an average annual processing of 2,000 t.year ${ }^{-1}$. At the same time (1998), the group SODIRO (Company for Industrial Development of the region of Odienné, in the north of Côte d'Ivoire) inaugurated a shelling unit of 2,500 t.year ${ }^{-1}$. This unit really started its activity in 1999 and stopped it in $2002[4,5]$.

The year 2001 was marked by falling prices of cashew in the global market. This situation and the politico-military crisis of September 2002 then brought about the closure of two factories in Côte d'Ivoire in 2002. This situation lasted until 2005, after which there was a reorganization of the sector marked by a resumption of activity of some units and the creation of others. In 2005, the plant SITA S.A. (Ivorian Processing of Cashew, Ltd.), ex-SODIRO, attempted to start its activities. In addition, a shelling unit 
Table I.

Cashew nut transformation (into tons) of various units of shelling [2] in Côte d'Ivoire.

\begin{tabular}{|c|c|c|c|c|c|c|}
\hline \multirow[t]{2}{*}{ Unit of shelling } & \multicolumn{2}{|c|}{2005} & \multicolumn{2}{|c|}{2006} & \multicolumn{2}{|c|}{2007} \\
\hline & $\begin{array}{c}\text { Cashew } \\
\text { nuts }\end{array}$ & $\begin{array}{l}\text { Cashew } \\
\text { kernels }\end{array}$ & $\begin{array}{c}\text { Cashew } \\
\text { nuts }\end{array}$ & $\begin{array}{c}\text { Cashew } \\
\text { kernels }\end{array}$ & $\begin{array}{l}\text { Cashew } \\
\text { nuts }\end{array}$ & $\begin{array}{c}\text { Cashew } \\
\text { kernels }\end{array}$ \\
\hline Olam Ivoire & 563 & 118.25 & 1866 & 391.91 & 3909.00 & 821.00 \\
\hline Sita S.A. & 0 & 0 & 0 & 0 & 1473.35 & 294.67 \\
\hline Fassou Cashews & 0 & 0 & 0 & 0 & 55.00 & 9.00 \\
\hline Coopabo & 0 & 0 & 76 & 15.75 & 90.00 & 15.00 \\
\hline Total & 563 & 118.25 & 1942 & 407.66 & 5527.35 & 1139.67 \\
\hline
\end{tabular}

of 5,000 t.year ${ }^{-1}$ was established in Dimbokro (N'Zi Comoé region) by the company Olam Ivoire. In Yamoussoukro, a unit of cashew was inaugurated in Fassou in 2006 and began operations in 2007 [2, 4]. Many small industrial handcrafted shelling units and collectives (cooperatives) (table I) emerged in the Zanzan, N'Zi Comoé and Savannah regions.

\section{Organization of the cashew sector in Côte d'Ivoire}

\subsection{Description and organization of production}

Production is generally carried out by small-scale farmers who have plantations with a production area that ranges between (2 and 5) ha. However, there are some industrial plantations created by the state of Côte d'Ivoire and graciously given to communities which own these lands. The average area of these plantations is between (150 and 200) ha [2]. As for production yields, they vary widely, for they are between (200 and 1,000) kg of cashew nuts $\mathrm{ha}^{-1}$. These returns depend on maintenance, level of fertility, population density and age of plantations [3].

Farmers use two types of cultivation: the nursery and the semi-direct. The nursery is based on a selection of fine nuts (large nuts) as germplasm. The semi-direct is done dur- ing the rainy season by planting seeds in pairs [3].

The production of cashew in Côte d'Ivoire extends from February to June. The constitution of stocks takes place between March and June. This raises a problem of fixing the prices of cashew in Côte d'Ivoire since the international market pricing takes place in August. Indeed, the production season of major cashew-producing countries (India, Brazil and Vietnam) has to be from August to December. In order not to take risks, exporters and factory owners buy the Ivorian cashews at a relatively low price. This production is almost entirely intended (95\% to 98\%) for export as raw nuts.

\subsection{Dynamics of cashew production}

Used in the 1960s to fight against erosion, the cultivation of cashew has become a perennial source of income for more than 150,000 farmers gathered in a score of cooperatives and allowing $1.5 \mathrm{M}$ people to earn a living [2]. This production follows an exponential growth (figure 1). Production rose from 6,000 t in 1990 to $330,000 \mathrm{t}$ in 2008, with a forecast of $350,000 \mathrm{t}$ in 2009 [2]. Unfortunately, this growth does not always benefit producers because more than 95\% of the production is exported in raw form, and the mechanism for setting prices is to their disadvantage. Out of the 19 regions in the country, cashew is produced in 11 regions (figure 2, table II). 


\section{Soro et al.}

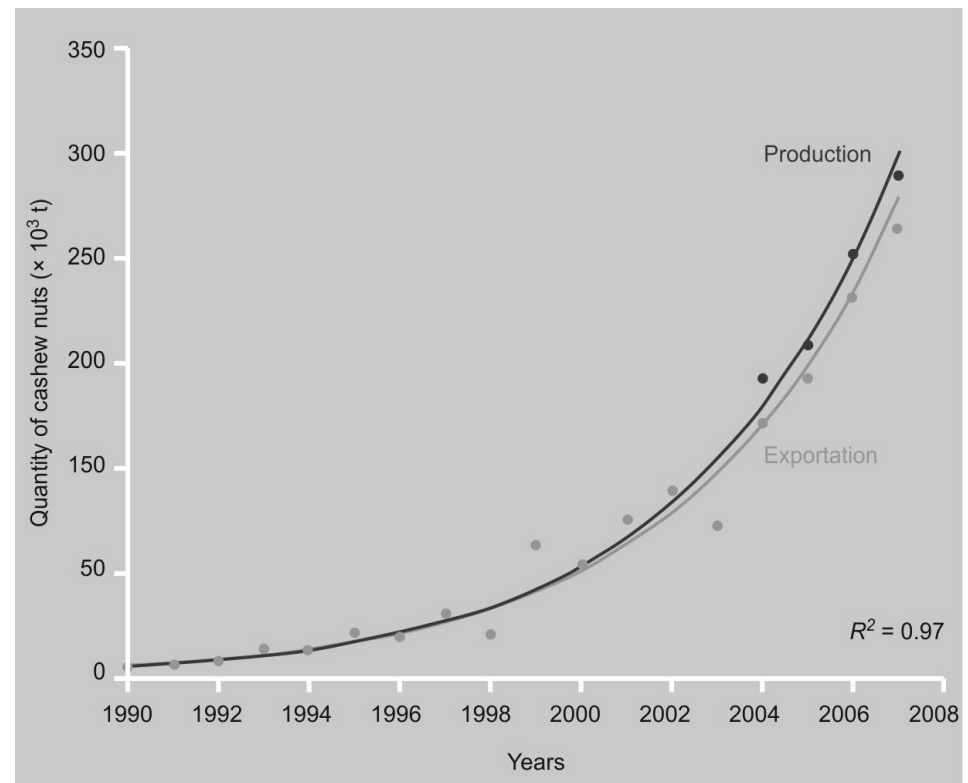

Figure 1.

Cashew nut production and export (t) in Cote d'Ivoire from 1990 to 2008 [2].

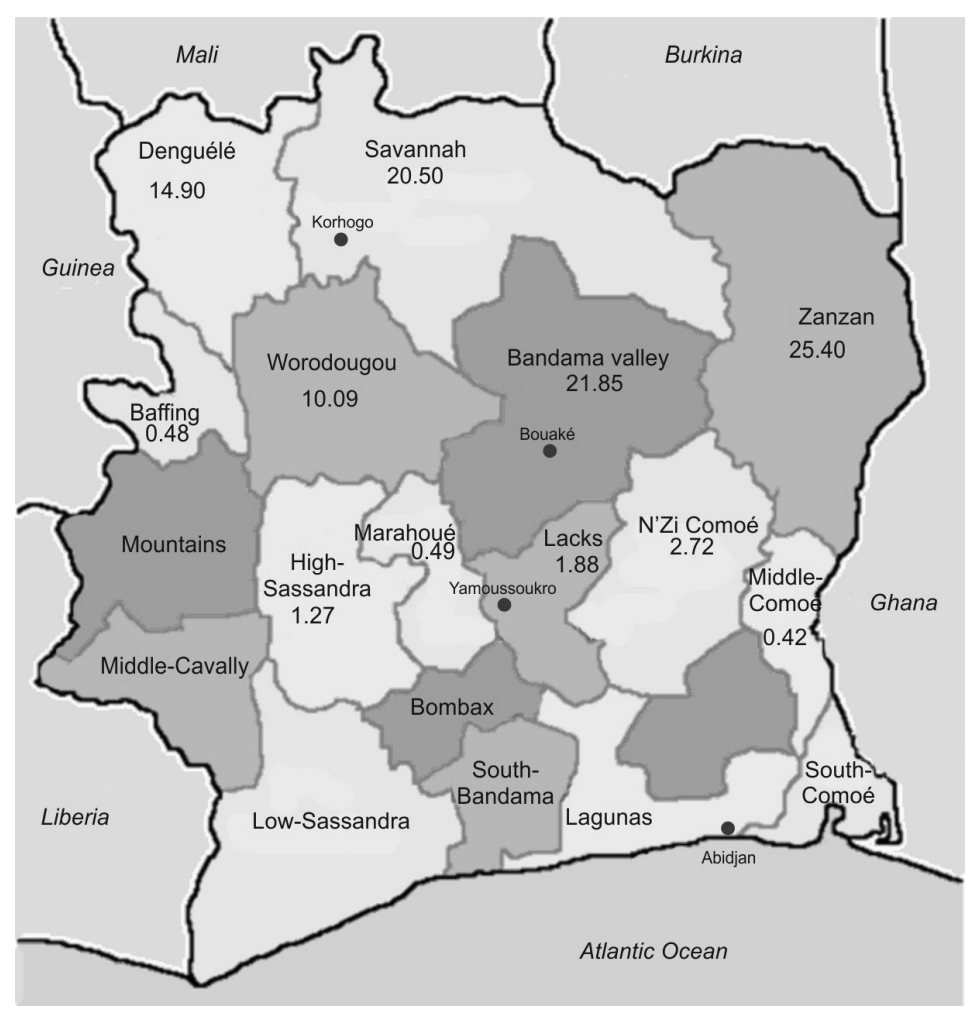

Figure 2.

Surface of the culture of cashew nuts in Côte d'Ivoire in 2007, expressed as a percentage of various areas of the country [2].
Table II.

Production of cashew nuts of various areas of Côte d'Ivoire in 2007 [2].

\begin{tabular}{lc}
$\begin{array}{l}\text { Area } \\
\text { of Côte d'Ivoire }\end{array}$ & $\begin{array}{c}\text { Production of cashew nuts } \\
(\mathrm{t})\end{array}$ \\
\hline Zanzan & 71,120 \\
Bandama Valley & 61,180 \\
Savannahs & 57,400 \\
Denguélé & 41,720 \\
Worodougou & 28,252 \\
N'Zi Comoé & 7,616 \\
Lacks & 5,264 \\
High-Sassandra & 3,556 \\
Marhoué & 1,372 \\
Bafing & 1,344 \\
Middle-Comoé & 1,176
\end{tabular}

\subsection{Description and organization of marketing}

The actors involved in the purchase and marketing of cashew nuts can be divided into four categories: trackers, buyers, traders and exporters. The first three categories are the intermediaries; in the absence of a regulator they impose their rules on producers.

\subsubsection{Trackers}

Trackers are men or women who reside in the same village as producers. They know the farmers and the villagers. They rely on buyers who advance them money to purchase nuts at a price fixed in advance [3]. Knowing the problems faced by farmers, they bid more. They play an important and decisive role in the picking of cashew nuts.

\subsubsection{Buyers}

Buyers work for merchants who advance them money to pre-purchase nuts at a price equal to a quota (tonnage). Each buyer may seek the services of several trackers based on the money he or she has. The trackers are paid per kg of nuts purchased. Generally the fee is between ( 5 and 10) $\mathrm{FCFA}^{1} \cdot \mathrm{kg}^{-1}$.

\subsubsection{Traders and cooperatives}

Traders and cooperatives are funded by corporations which give them the working

\footnotetext{
${ }^{1} 100 \mathrm{FCFA}=0.15 €$.
} 
capital required for each contract at prices set by the cashew professional body. Cashew nuts collected are sent to the store rooms of trading companies. Depending on the contract of the corporation, each merchant may seek the services of more than one hundred buyers.

\subsubsection{Commercial companies and processing plants}

Commercial companies and processing plants are the last link from which the raw or processed nuts are taken out of Côte d'Ivoire. Besides these companies and factories, it is worth noting the presence of Indian businessmen who export raw nuts.

Commercial companies in Côte d'Ivoire are AFRECO, Olam Ivoire and Civiv. Those with plants processing more than 1,000 t. year ${ }^{-1}$ are Olam Ivoire and SITA S.A.

AFRECO (African Trade), which was established in 1972, specializes in the export of cashew nuts and other products such as coffee, cocoa, cola nuts, bee wax, etc. It was the largest exporter of raw nuts from 1999 to 2002. Its strength is that it has permanent representations in major production areas of cashew.

Olam Ivoire is a multinational company based in London (UK). It has been present in Côte d'Ivoire since 1994 and specializes in the purchase and export of agricultural and forest products such as cashew nuts, shea nuts, timber, etc. Regarding the purchase of nuts, this company is present in the Savannah area (Korhogo, Ferkessédougou and Ouangolodougou), and in the areas of Bondoukou, Katiola and Odienné. It was the largest exporter of cashew until 1998.

Civiv (Ivorian industrial and commercial company) ranks third in Ivorian cashew export.

\subsection{Organization chain management}

In view of the high production of cashew, the state of Côte d'Ivoire created in 2002 the ARECA (Cotton and Cashew Nut Regulation Authority). The mission of this body was control and arbitration in these two sectors.
ARECA is a state body; in February 2005, the producers, the exporters and the factory owners organized to create OTIFA (Transitional Body of the Joint-Trade Organization of Cashew). This organization is responsible for establishing the joint-trade organization of the cashew sector. The missions of OTIFA are:

- monitoring the proper conduct of the campaign,

- representing the industry with governments, donors and other development partners,

- involvement on behalf of operators in the organization of the chain.

Given the difficulties OTIFA had in establishing the joint-trade organization of the cashew industry and the conflicting relationships with ARECA, producers were grouped within the FENOPACI (National Federation of the Producers of Cashew in Côte d'Ivoire). The Federation's mission was the search for direct contracts with manufacturers in India, Brazil and Vietnam, ensuring a high price on the field to producers.

The cashew joint-trade organization was finally established on December 12th, 2007 under the name INTERCAJOU. It now sets the price on the field per kilogram of cashew at the beginning of each campaign. The price changes depending on the price per $\mathrm{kg}$ on the international market.

\section{Strategic and institutional environment}

\subsection{Strategic}

Given the enthusiasm generated by the cashew industry and problems related to cotton due to lower revenues, it is desirable that the state of Côte d'Ivoire organizes the cashew sector. Indeed, it is the cotton farmers who also produce cashew nuts. For a good social cohesion and the fight against regional disparities, the sector is attracting increasing attention from governments. But decisions made at the top of the state do not 


\section{Soro et al.}

always seem to meet the producers' expectations, who are the main link in this chain.

To ensure the sustainable and comprehensive development of the sector, Côte d'Ivoire has research centers and frameworks that can assist farmers in their organization.

CNRA (National Center for Agricultural Research) will establish an evaluation program of plant material to select varieties with high yield. The example of Brazil is a good one to follow as, through its research center EMBRAPA (Empresa Brasileira de Pesquisa Agropecuária), it came to select varieties with yield production of $5 \mathrm{t} \cdot \mathrm{ha}^{-1}$.

ANADER (National Rural Development Support Agency) will disseminate research and mentor planters. Not only will the framework of ANADER improve production yields by maintaining the plots, but it will also disseminate farmers' practice in intercropping crops such as groundnuts, maize, yams, cassava, soybeans, etc.

In the promotion of co-products such as cashew apple, which is five to nine times the weight of the nuts, research structures such as I2T (Institute of Tropical Technology) and DFR-GCAA INP-HB ( Training and Research Department in Chemical Engineering and Agri-food of the Polytechnical Institute Félix Houphouët-Boigny) should train the producers in the processing techniques of this commodity.

It is important to install shelling units in areas of production. This initiative must be taken for two major reasons. The first is that the benefit of shelling nuts in Côte d'Ivoire provides a saleable product directly to Europe and the United States of America (USA), while raw nuts are shipped to India where they partly return to Europe and the USA after shelling. This detour is a loss to Côte d'Ivoire. The second reason is that it is Indian buyers who are paying for $90 \%$ of the Ivorian production, and on the day when India ensures self-sufficiency in raw nuts, it will no longer need Ivorian nuts [5].

In order not to remain on the sidelines of this growth, today it is about creating about 120 units of medium transformation $\left(2,500 \mathrm{t} \cdot \mathrm{year}^{-1} \cdot \mathrm{unit}^{-1}\right)$ to dissect the entire Ivorian production. This initiative must be taken by the Ivorian political authorities in encouraging foreign investors to settle. This will allow Côte d'Ivoire on the one hand to establish its own agro-industries and to leave its position as supplier of raw nuts to position itself as a supplier of almonds to create about 36,000 direct jobs and 50,000 indirect jobs; and, on the other hand, to conquer a market of over 300 billion FCFA.

Producers for the renewal of plantations should be eligible for bank loans or state subsidies and leadership by the organizations mentioned. Indeed, the former plantations that were created in the context of reforestation are old. To keep the same dynamic growth, continuous renewal is necessary. The state should establish a mechanism facilitating the renewal of these plantations. This support may be a subsidy for farmers, as in the case of cotton, or the establishment of an agricultural bank that may make loans to farmers at low repayment rates.

\subsection{Institutional environment}

The survival of an industry depends on its organization and the coordination of the activities of the different actors in this sector. Concerning the cashew sector in Côte d'Ivoire, it is rather the disorganization and the lack of coordination of operators (producers, processors and exporters) that is noticed. This is reflected by the change in price per kg during the same campaign. This variation is due to the fact that it is only the exporters that impose the price. This price is determined primarily by the Indian buyers. They enjoy the fact that there is not a homogeneous quality charter setting the quality parameters of cashew. They have their own criteria they impose, and more often they manage to devalue the product to keep prices low. They send their own screeners, while there are two companies that operate in quality control and certification in Côte d'Ivoire.

To fight against this fraud, operators must establish an institutional environment in which the rules are set. Thus, the different quality standards are defined in a concerted 
manner between the operators (producers and buyers) under the arbitration of the state.

Noting all this dysfunction, the state must therefore establish an institutional framework to prevent any disorder. Thus, quality analysis will be carried out by either of these two bodies that exist: "Bureau Veritas" and SGS (General Surveillance Company). Any dispute must be endorsed by a second opinion.

A major problem in this sector is the nonsubmission of foreign buyers (especially Indian) to the same charges of tax. They are less taxed than local buyers. Not only is the local buyers' fee high but also loans awarded from local banks have high repayment rates (approximately 19\%), while the fee of Indian buyers is low (about 4\%). The state must also harmonize taxes in such a way that local buyers are not prejudiced and it must make the mechanism for granting loans flexible by reducing reimbursement rates.

Finally, the state should encourage private investors who wish to transform the cashew industry locally by easing up on taxation.

\section{Transformation potential}

One of the major handicaps of the cashew sector is not processing the commodity. Indeed, less than $5 \%$ of production is processed locally. This low level of industrialization is mainly due to two major obligations [3].

The first one is financial. Indeed, the operators are unable to obtain bank financing for the establishment of factories. The period of application is generally longer for investors and eligibility criteria for projects with private commercial banks are binding and inappropriate [3]. They must provide a bank guarantee of from $75 \%$ to $100 \%$ of the amount requested in more than $40 \%$ equity they should have. As for the World Bank, given the failures of the first experiences of industrialization, it is prejudiced about the viability of processing units of cashew in Africa.

The second obligation is institutional. Some tax provisions of the investment code in Côte d'Ivoire, in particular those related to the amount of the cost of imported equipment, do not promote the industrialization of the cashew sector. Indeed, the amount of investment for units processing approximately $2,500 \mathrm{t}$ of raw nuts year ${ }^{-1}$ does not reach the minimum required to qualify for exemptions under the investment code [3].

To develop the industrialization of the cashew sector, the state must engage with commercial banks to reduce bank guarantees and also make adjustments in the investment code. These improvements will focus on reducing the amount of the cost of imported equipment and will also permit entitlement reductions and tax exemptions. This will promote the installation of foreign and local investors, as the raw material is available $\left(330,000 \mathrm{t} \cdot\right.$ year $\left.^{-1}\right)$.

The perfect command of applied technology is very important in the cashew sector. In fact, this sector employs many workers ( 500 persons per one unit of 2, $500 \mathrm{t}^{\mathrm{ye}}$ year ${ }^{-1}$ ). The payroll is significant and requires an optimization of production. This optimization is possible if the staff is well trained. It is the strong point of the Indian and Brazilian industries, where female staff is welltrained in the shelling of cashew nuts and almond pruning.

The example of the Brazilian company CIONI (Companbia Industrial de Óleos do Nordeste) in the state of Ceara should inspire Ivorian investors. This company, founded in 1963 with an annual production of $100 \mathrm{t}$, today transforms between $(25,000$ and $30,000) t \cdot y^{-1}{ }^{-1}$. It is the largest factory in the world for processing cashew nuts and it employs over 8,000 people in cashew season.

Finally, the promotion of the cashew apple, a co-product of the nuts, will help stabilize the exploitation of cashew trees. In fact, the cashew apple is five to ten times the weight of the nuts. With the Ivorian production that is $330,000 \mathrm{t}$ of cashew nuts; this is more than $3 \mathrm{Mt}$ of cashew apples. A great amount of this production is lost because 
the harvest of cashew apple is not exploited commercially in Côte d'Ivoire. This raw material has a great nutritional potential. It is very rich in vitamin $\mathrm{C}$, carotenoids, polyphenolic compounds, sugars and minerals needed for human consumption [6-11]. The main way of promoting it that is relevant for consideration is juice processing because of its richness in water ( $80 \%$ to $90 \%$ ) and sugar (10\% to $12 \%$ ). It can also be canned in syrup, and used to make jams, fruit jelly, jelly, candied fruits, wine, alcohol, vinegar, etc. [6].

\section{Conclusion}

The cashew sector in Côte d'Ivoire is booming. However, the fact that farmers are not organized in professional bodies is reflected in all sorts of speculation by intermediaries. Similarly, the lack of organization of different operators (farmers, processors and exporters) in the sector does not promote collaborative resolution of issues of common interest. The various structures put in place must work in synergy to boost this sector, which can help Côte d'Ivoire put an end to the crisis, because development is always a precursor to peace. Finally, the establishment of a regulatory and institutional framework will encourage investors in the sector to create cashew processing units that will generate income. It will also favor the promotion of the cashew apple, which can be processed into juice to compete with those existing in the world market [12-14].

\section{Information}

Most of the information and figures in this article were drawn from reports of ARECA (Cotton and Cashew Nut Regulation Authority), a state structure established by the Ministry of Agriculture of the Republic of Côte d'Ivoire.

\section{Acknowledgments}

This work was possible thanks to the financial support of the French Embassy in Côte
d'Ivoire through a grant to one of the authors.

\section{References}

[1] Rey J.-Y., la noix de cajou en Côte d'Ivoire en forte progression, FruiTrop 51 (1998) 12-13.

[2] Anon., Documents internes de l'Autorité de Régulation du Coton et de l'Anacarde de Côte d'Ivoire, ARECA, Abidjan, Côte d'Ivoire, 2009.

[3] Diabaté G., Analyse du secteur de l'anacarde en Côte d'Ivoire : situation actuelle et perspective de développement ; Rapport du Centre de commerce international CNUCCED / OMC (CCl), Abidjan, Côte d'Ivoire, 2002, $34 \mathrm{p}$.

[4] Bamba B.S.B., Étude des rendements et du coût de production des unités de décorticage de noix de cajou de COPABO, École supér. Agron. INP-HB, mém., Yamoussoukro, Côte d'Ivoire, 2007, 41 p.

[5] Soro D., Optimisation de la production des amandes entières blanches de cajou, Ecole supér. Agron. INP-HB, mém., Yamoussoukro, Côte d'Ivoire, 2002, 54 p.

[6] Lautié E., Dornier M., Fihlo de Souza M., Reynes M., Les produits de l'anacardier: caractéristiques, voies de valorisation et marchés, Fruits 54 (2001) 235-248.

[7] Assunção R.B., Mercadante A.Z., Carotenoids and ascorbic acid composition from commercial products of cashew apple (Anacardium occidentale L.), J. Food Compos. Anal. 16 (2003) 647-657.

[8] Assunção R.B., Mercadante A.Z., Carotenoids and ascorbic acid from cashew apple (Anacardium occidentale L.): variety and geographic effects, Food Chem. 81 (2003) 495-502.

[9] Santos R.P., Santiago A.A.X., Gadelha C.A.A., Cajazeiras J.B., Cavada B.S., Martins J.L., Oliveira T.M., Bezerra G.A., Santos R.P., Freire V.N., Production and characterization of the cashew (Anacardium occidentale L.) peduncle bagasse ashes, J. Food Eng. 79 (2007) 1432-1437.

[10] Carvalho Pereira Campos D., Santos A.S., Wolkoff D.B., Martins Matta V., Corrêa Cabral L.M., Couri S., Cashew apple juice stabilization by microfiltration, Desalination 148 (2002) 61-65. 
[11] Abreu Fernando A.M.P., Dornier M., Reynes M., Potentialités de la microfiltration tangentielle sur membranes minérales pour la clarification du jus de pomme de cajou, Fruits 60 (2005) 33-40.

[12] Sabbe S., Verbeke W., Van Damme P., Analysing the market environment for açaì (Euterpe oleracea Mart.) juices in Europe, Fruits 64 (2009) 273-284.
[13] Daufy V., Peltier R., The Chilgoza of Kinnaur, Inluence of the Pinus gerardiana edible seed market chain organization on forest regeneration in the Indian Himalayas, Fruits 64 (2009) 99-110.

[14] Speelman S., Sáenz-Segura F., D’Haese M., The influence of contracts on smalholder pepper (Piper nigrum L.) producers in Costa Rica under different market conditions, Fruits 64 (2009) 371-362.

\section{La industria de la nuez de anacardo (Anacardium occidentale) en Côte d'Ivoire: Elemento de análisis y perspectivas para su desarrollo.}

Resumen - Introducción e historia del cultivo del anarcado. La situación geográfica de Côte d'Ivoire favorece el cultivo del anacardo (Anacardium occidentale) en la mitad norte del país. En efecto, este sector de actividad, introducido en los años 1960 para luchar contra la erosión y frenar el avance del desierto, se volvió un cultivo perenne, generador de ingresos para más de 150000 productores, agrupados en unas veinte cooperativas, que permiten vivir a más de 1,5 millones de personas. Por lo tanto, la producción pasó de 6000 t año ${ }^{-1}$ en 1990

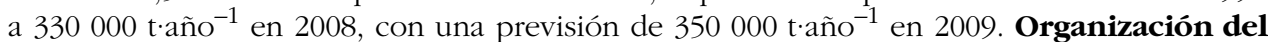
sector del anacardo. Sin embargo, este sector de actividad se ve enfrentado a enormes problemas, como, por ejemplo, la desorganización de los operadores y la no transformación de la nuez de anacardo. La desorganización de los operadores de este sector de actividad no favorece la resolución de común acuerdo de los problemas de interés común. Esto se traduce a todo tipo de especulación por parte de los intermediarios. Las estructuras existentes no trabajan conjuntamente, por lo que el precio del kilo de anacardo pagado a los productores varía dentro de un mismo campo, de una región a otra e, incluso, en función de los compradores. Estrategia y entorno institucional. Los problemas de transformación de las nueces de anacardo, por lo que a ellos se refiere, se deben, por un lado, al código de inversión que no favorece la instalación de unidades medias de transformación (2 00 t $\left.\cdot a n o^{-1}\right)$ y, por otro lado, a las bancas privadas, que exigen demasiadas garantías para financiar a los inversores. Conclusión. El sector de actividad de la nuez de anacardo tiene futuro en Côte d'Ivoire, siempre y cuando los operadores se organicen y que el Estado instaure un marco reglamentario e institucional para favorecer la instalación de los inversores.

Côte d'Ivoire/ Anacardium occidentale / anacardo / industria / corrientes de mercadeo / industrias cooperativas / información situación del mercado / formación de precios 